\title{
The Solution to Safety Crisis in Railways after Privatisation
}

\author{
By Hiroki Ito ${ }^{1}$
}

\begin{abstract}
Privatisation of infrastructure is expected to improve the effectiveness of operation, whereas it is possible to cause excessive rationalization. Especially in the field of railways, excessive rationalization causes fewer investments in the maintenance of assets and undermines safety. Railways play a critical role to develop the economy in a sustainable way and have a significant impact in the region, but their safety must be prioritised. In fact, the UK government privatised British Rail and founded Railtrack, which was specialised in the railway track maintenance, but the Hatfield accident raised awareness for safety and led to the renationalising Railtrack into Network Rail. Likewise, in Japan, National Railways was privatised and divided into separate companies (JR), but among them JR Hokkaido has been causing a large number of accidents and troubles. Based on the review of the process and outcomes of the privatisation of railways in the UK and Japan, this paper discusses the way to improve their safety sustainably. In conclusion, it validates the intervention of governments in railway companies suffering from poor financial health.
\end{abstract}

Keywords: Privatisation, Railways, Safety, British Rail, Railtrack, Network Rail, Governmental intervention

\section{Introduction}

Privatisation has been implemented in various fields of infrastructure such as water, electricity and telecommunication. Especially, railways, one of the major transportations, were privatised in several countries such as Britain and Japan, and some studies positively evaluate their achievement (Pollitt, M.G. and Smith, A.S.J. 2002; Hirooka 1997). Privatisation of railways is expected to result in positive outcomes such as the increase in revenues, the progress in rationalisation and the improvement in services.

On the other hand, privatization is possible to bring about excessive rationalization, which causes adverse effects such as closing lines, decreasing the numbers of train services and devaluing safety. Among these issues, securing safety must be universally prioritised in transportation. In Britain, actually, the Hatfield accident raised awareness for safety and led to renationalising Railtrack, responsible for the railway track maintenance, into Network Rail. This renationalisation means that the railway track maintenance, once being privatized, was put back to being under state control. Abe (2014) points out that the lack of investment into equipment and maintenance can be attributed to the fact that Railtrack as a private company needed to cope with dividends for its shareholders and lacked investments into equipment and maintenance. Likewise, in JR (Japan Railways) Hokkaido, there has been a large number of accidents and troubles caused by broken equipment, which cannot be irrelevant to its unstable management. Therefore, while acknowledging that privatization can achieve positive effects, it is vital to create well-balanced policies 
considering its negative aspects. The renationalisation of Railtrack into Network Rail is thought-provoking for reconstructing JR Hokkaido.

This paper discusses and compares the privatisation of railway track maintenance in Britain and Japan, and then thinks about the ways to improve safety in JR Hokkaido sustainably.

\section{Privatisation of British Rail (BR)}

\subsection{Backgrounds}

From its nationalisation in 1948 to privatisation in the mid-1990s, railways in Britain faced the decline in its share in passenger traffic due to the severe competition from vehicles (the share decreased from $17 \%$ to $5 \%$ ). The railways fell into a loss-making industry in the mid-1950s, so it closed some lines and stations, but it could not stop its worsening financial conditions. As its performance deteriorated, the number of subsidies put from the government expanded from $£, 600$ million in 1968 to $£ 1.6$ billion in 1985 (166\%). From 1981, the government and BR decided to sell off BR's non-core business such as hotels and advertising in an attempt to reconstruct BR's financial situation, but the demand for the privatisation of BR grew gradually strong (Pollitt, M.G. and Smith, A.S.J. 2002).

The controversy over privatising the railway operation did not stop in the 1980s and 1990s. The Conservative Government mentioned the privatisation of railway in a White Paper (Department of Transportation 1992). As Britain had undertaken privatisation in gas and electricity in the 1980s, The Conservatives aimed to introduce competitive market forces and private ownership to distribute resources more efficiently (Crompton and Jupe 2003). They expected that making efforts to push down costs would lead to more efficiency, and hoped for the higher level of services and the reduction in public subsidies.

\subsection{Details}

The most radical and controversial change was that the maintenance of the track became independent from train services and operation. The authority responsible for infrastructure, that is Railtrack, was privatized and made separate from BR in 1996, and rail businesses were sold off by 1997. The BR's infrastructure system was fragmented and reorganised into multiple independent companies; Railtrack, 25 franchised passenger train operating companies (TOCs), seven infrastructure maintenance companies, six track renewal companies and three rolling stock leasing companies. TOCs were required to pay the track access charges to Railtrack, which guaranteed Railtrack incomes. Track maintenance and renewal were outsourced to the infrastructure companies.

\subsection{Outcomes and evaluations}

The privatisation of BR enabled the railway industry to become more productive and efficient. After being reorganized and transferred to the private sector, passenger miles increased from 228million to 257million (113\%) between 1992/93 and 1999/2000, and freight tonne-miles from 9.6 billion to 11.4 billion $(119 \%)$. In the same period, the total operation cost went down from $f^{4,406}$ million to $f^{4,155}$ million (94\%), which suggests that efficiency was improved. Furthermore, the revenues of 25 train operating companies altogether went up from $£ 4.6$ billion in 1997 to $£ 5.8$ billion $(126 \%)$ in 2003. 
Despite the improvement of performance and costs, some studies explain the negative impacts of the privatisation. For example, Shaoul (2006) states that the fragmented railway industry in the UK cannot endure their high operating and investment costs only by the fare, and criticises that they depend on public subsidies ( $f 1.5$ billion in 2010$)$ to cover the costs. Terry (2001) insists that low qualities of rolling stocks are leased to TOCs due to the short franchises and that demands of passengers are not reflected.

Looking at safety, the National Audit Office (NAO) report (2000) notes that the number of broken rails climbed from 750 in 1995/96 to 937 in 1998/99. The report emphasises the lack of a comprehensive network of an asset registration system and claims that the registration system is crucial to the assets management. Actually, there happened a series of accidents such as the Southall rail crash in 1997. Especially in the aftermath of the Hatfield accident (2000), a derailment accident where four people died and 70 people got injured, BR faced severe criticism of safety. Most of the criticism was drawn by Railtrack. The reason for the derailment lay in the cracks on the rail; it was crashed into more than 300 pieces for $35 \mathrm{~m}$ after the accident. Terry (2001) insists that the safety of railways was put at risk due to the loss of corporate culture, which used to develop safety. The infrastructure system was maintained by fragmented companies after the privatization, so the corporate culture was weakened alongside. Crompton and Jupe (2003) state that the Hatfield accident can be attributed to rail's fragmentation and that the corporations could not work in collaboration beyond organisational boundaries.

In addition to the organisational structure, the lack of investment into railway tracks is pointed out to be another reason for the accidents. Daigo (2006) mentions the report on Southall rail crash (2000), which insists that Railtrack as a private company assumed a duty to pay dividends to shareholders ( $£, 138$ million in $2000 / 01)$, so it could not secure financial resources put into infrastructure investment. He also notes that one of the means to acquire the financial resources is to push down the dividends, but it is impossible for Railtrack to do so because of the necessity of benefiting the shareholders.

As a result, in October 2001, the British government announced that it decided to place Railtrack into governmental administration. Afterwards, in 2002, BR was replaced with a public interest company limited by guarantee, Network Rail. Unlike Railtrack, it has no shareholders and does not need to pay dividends. Network Rail does not have to consider shareholders' interests (Jupe 2011).

The performance of Network Rail has advantages and disadvantages. Network Rail successfully renewed and improved its infrastructure, and enhanced the safety and the service (Pamungkas and Muthohar 2017). On the other hand, Network Rail has to rely on subsidies expenditures for maintenance ( $£, 5.2$ billion including TOCs in 2006/07) and suffers from expanding debts ( $£$, 9.7 billion in $2002 / 03$ to $£ 18.4$ billion in $2006 / 07$ ). It is anticipated that the subsidies for them will continue to rise (Shaoul 2006).

\section{Privatisation of Japanese National Railways (JNR)}

\subsection{Backgrounds}

Japanese National Railways (JNR) was established as a public corporation in 1949, 
according to the Railway Nationalization Act. JNR assumed a critical role in transportation in Japan after World War II and amounted to 55\% of the total passenger transport in 1955 (MLIT 2017). JNR mainly attempted to realize "public nature" such as shaping and maintaining the countrywide railway network and providing fair services (Abe 2014). Its fares, wages, budgets, investments and personnel management were controlled by the Japanese government, so its management team was not eligible to make decisions and the management was devoid of efficiency.

Because of the increasing popularity of vehicles and the development of motorways (Matsubara 1996), JNR gradually faced difficulty in their management. It fell into the red in 1964, and their deficit operation lasted until their privatisation. The amount of annual deficit plus subsidies from the government in the last five years before the privatisation exceeded three trillion Japanese yen ( $£ 21$ million), and the total number of debts amounted to 37 trillion Japanese yen. Their management style left the deficit operation unsolved (Matsubara 1996). Since it was a public corporation, which is apart from the government itself, the government was not in the position of being blamed for the deficit. At the same time, it could receive an infinite number of debts from the government as it was established by the government. It also constructed a series of train lines which they did not expect to be profitable enough.

\subsection{Details}

There were four internal deficiencies about its management (MLIT 2017; Hirooka 1997). (1) It was heavily intervened by the government and the parliament, such as in budgets and personnel relocation. (2) Its management team was given limited authority, and their management responsibility was not defined clearly. (3) Its relationship with the trade unions was anomalous, and collective bargaining was not done in a healthy way. (4) Its business field was strictly regulated, which made the management less elastic and diversified. In addition to these points, it operated in a uniform but less efficient and less competitive way as it covered all the regions in Japan as a sole organization.

Fig.1 Six JR companies

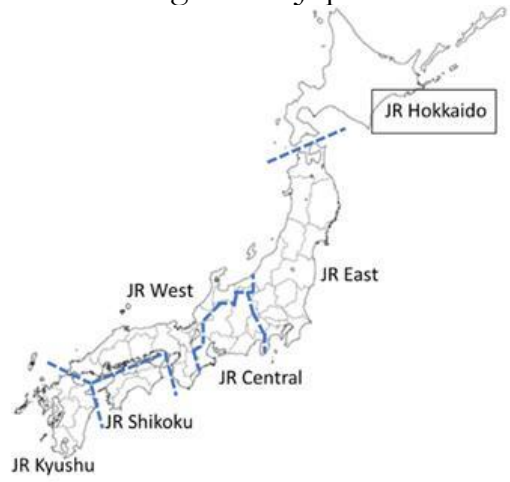

To address these problems, JNR was privatized, and divided into six passenger railway companies (JR; Japan Railways) and one freight railway company (JR Freight; Japan Freight Railway Company). Among six JR companies, three operates in the mainland of Japan, and the other three JR companies in other three islands (Hokkaido, Shikoku and Kyushu), respectively (Fig. 1). The reason why JNR was divided into multiple companies was that it 
was required to overcome its uniform operation and adjust its services to demands in each region, and to drastically reform staff consciousness.

As they were expected to be in the red, debts were not passed onto JR companies operating in the three islands, one of which was Hokkaido Railway Company. Instead, new funds worth 1.3 trillion Japanese yen were founded (Management Stability Fund), and the return was used to compensate for the deficit. Hokkaido Railway Company was allocated with about $53 \%$ of the funds. JR Hokkaido is a private company, but none of its stocks has been sold to private sectors by 2014. All the stocks are owned by Japan Railway Construction, Transport and Technology Agency (JRTT) controlled by MLIT, so JR Hokkaido is equal to being owned by the Japanese government.

\subsection{Outcomes and evaluations}

One of the main achievements which resulted from the privatisation is the improvement of management strategy and service quality (MLIT 2017, Hirooka 1997). JR companies succeeded in speeding up and increasing the operation of their trains. They also improved the connection with private railways, popularised IC cards, promoted the accessibility to stations, developed new stations and introduced sightseeing trains. As a result, they improved healthiness and profitability of their business. Although three JR companies outside the mainland are still in the red, all the seven JR companies increased their operating revenues and profits after the privatization. The total number of passengers of six JR companies increased by 32\% in 2015 compared with 1987. By 2016, four out of them have become listed in the stock market and wholly privatised.

Adverse outcomes, however, must not be overlooked. By February 2017, JR companies altogether have closed seven train lines due to the decrease in passengers and the development of substituting transportation (MLIT 2017). Four of the lines were in Hokkaido. These movements relate to pursuing efficiency caused by the privatisation. Another problem lies in JR in the three islands. They all suffer from the deficit balance in 2011. In the three islands, the relatively low density of inhabitants and the widespread use of vehicles make the train operation itself unprofitable and unsustainable. Management Stability Fund, the purpose of which was to cover the deficit by the return, did not work because of the low-interest rates under the depression in the 1990s.

\section{Crisis in Hokkaido Railway Company}

\subsection{Current situation}

Unlike 3 JR companies in the mainland, Hokkaido Railway Company (JR Hokkaido) generates operating loss worth of 30 billion Japanese yen ( $\AA^{210}$ million) every year. In 2016, it announced that it would no longer independently sustain ten lines (13 sections, $1,237 \mathrm{~km}$ ), which are equivalent to half their whole line in length. There are 56 municipalities along the lines in total, and none of them approved (Miyashita 2017).

Structurally, railways do not suit the severe circumstances in Hokkaido, so they cannot be profitable and sustain their management only by their fare yield. The total population was about 5.7 million in 1987, but it had declined to 5.4 million by 2011. In 2012, the density of population was about 70 people per $\mathrm{km}^{2}$, which was about one-fifth that in the mainland (340 people per $\mathrm{km}^{2}$ ). Moreover, heavy snow makes it impossible to investigate and 
maintain their railway tracks during winter.

\subsection{Safety issues}

JR Hokkaido faces structural problems (Abe 2014); (1) accidents and troubles, (2) the collapse of moral as employees and an organisation and (3) unhealthy governance. Safety, which railways must absolutely protect, matters to all these three points.

Especially, railway track accidents have happened frequently in recent years. In May 2011, an express train derailed and burned, which resulted in 79 injuries. On top of that, in April and September 2012 and in August and September 2013, there happened a series of derailments. Also, Hokkaido Railway Company left 270 cracks in railway tracks unrepaired and submitted false data to the Japan Transport Safety Board.

These injustices are related to the moral hazard within the company. Against them, in January 2014, Ministry of Land, Infrastructure, Transport and Tourism (MLIT) issued an order to mitigate the situation, dictating eradicating falsification and restructuring the maintenance system. Accepting the order, in March 2015, Hokkaido Railway Company created a plan for investment and maintenance covering the following five years and reported it to MLIT. The Japanese government decided to put additional financial supports amounting to 120 billion Japanese yen ( $£ 838$ million).

\subsection{Background of safety issues}

The frequent accidents can be attributed to the massive retrenchments (Abe 2014). Under the retrenchments, JR Hokkaido has to curtail investments in maintaining assets. JR Hokkaido has been facing falling return from Management Stability Fund and operating revenues; from 1987 to 2012, the former decreased from 50 billion Japanese yen ( $£ 350$ million) to 27 billion Japanese yen ( $£, 190$ million), and the latter decreased from 9.2 billion Japanese yen ( $\_, 644$ million) to 8.4 billion Japanese yen ( $f, 588$ million).

Despite the declines in income sources, operating loss shrank from 5.4 billion Japanese yen ( $£ 378$ million) to 3.1 billion Japanese yen ( 217 million) from 1987 to 2012 . It was labour costs and maintenance costs that drove down the operating loss. The total number of employees was 13 thousand in 1987, but it went down to seven thousand in 2012 because of rationalisation. Also, there are delays in the renovation of old rolling stocks. The shortage of financial and human resources thrusted JR Hokkaido into neglecting broken railway tracks and intentionally manipulating measured figures.

\section{Discussion -Governmental Intervention-}

So far, this paper has compared Britain and Japan in terms of their background, process and evaluation of privatisation. Especially, they have different characteristics of railway maintenance. In Britain, Network Rail has responsibility for railway maintenance independently from BR. BR was organized as a result of re-nationalising Railtrack on reflection of safety issues. Despite its reliance on subsidies and debts, Network Rail successfully ensures the safety of railway services. In Japan, on the other hand, especially JR Hokkaido faces deficits and accidents. The primary reason for the accidents is that JR Hokkaido has been reducing investments in railway maintenance, and the moral of employees is declining. Looking at investments, JR Hokkaido, as a private company, 
cannot raise funds due to deficits. This report discusses the validity of governmental support from two perspectives; financial support and technical support.

1) Financial support

Given the attributes of Hokkaido, which is unsuitable for railway services, it is difficult for JR Hokkaido to recover from deficiency. Even now, JR Hokkaido is given massive subsidies from the Japanese government (MLIT 2017). Financial support for private companies from governments is often controversial because the costs come from taxpayers' money and because prioritising a specific company lacks fairness. Railway companies, however, are a utility business mattering to tremendous numbers of inhabitants in the region, so the decline or loss of services would undermine their quality of life and cause severe economic damage. Therefore, financial support itself can be valid, but it is necessary to reduce its amount.

2) Technical support

In addition to financial support, technical support is of great importance to solve the problems facing JR Hokkaido. Highly technical knowledge and experience are essential to reducing waste of money invested in railway maintenance. Railway engineers must develop their technology mainly through experience which they can gain when they actually work, and it is necessary to have ten years of career to complete their work (Abe 2014). However, the number of employees who quit before the retirement age has been passing 100 every year since 2016 (The Hokkaido Shimbun Press 6 ${ }^{\text {th }}$ Jan 2020). This trend prevents the technique from being passed down onto the younger generations. As the total population in Japan has been decreasing, it is also essential to introducing advanced technique so that maintenance can be undergone efficiently with fewer engineers. Technical support includes cultivating professional ethics as a railway engineer.

\section{Proposal}

\section{1) Increase technical supports}

It would make little progress for the Japanese government to demand that JR Hokkaido should create and the submit reconstruction plan. Instead, the Japanese government should intervene with JR Hokkaido more practically and propose a statutory scheme. One form is to legitimise technical support. Although JR East sends engineers to JR Hokkaido, there are no institutions about technical support as far as I have checked. It is crucial to saving JR Hokkaido collectively.

\section{2) Divide the company into sales and maintenance department}

Railway companies in Britain operate in this way (so-called "two-tiered system"). In JR Hokkaido, it is worth thinking about separating the maintenance sector from the sales and management sectors and putting it under governmental control. The sales and management sector as a private company would pursue profits. The maintenance sector, on the other hand, under government control, would make sufficient investments in assets while minimising wastes.

One possible issue is information asymmetry. When trouble happens in assets and the train operation is delayed, it is of great importance to exchange information such as about the expected time of recovery or the number of affected passengers, and to provide the passengers with detailed information. This paper proposes creating an independent agency 
coping with the troubles, whose staff would be sent from the two sectors.

\section{3) Make conditions for implement privatisation}

Privatisation widened the gap among the JR companies; three JR companies in the mainland has been keeping in black, unlike JR Hokkaido. This paper claims that the privatisation should have been restricted to companies which were anticipated to be profitable if privatised. If profitability was not expected, it was not desirable to privatise it. It was right to have privatised JR companies in the main island, which actually yield profits, but JR Hokkaido should not have been privatised as it is now but instead reconstructed under the authority of the governments. At that time, the government should have discussed how to improve the performance of JR Hokkaido without privatisation. This rule should be applied when thinking about privatising other public companies in the future.

\section{Conclusion}

In Britain, the privatisation of BR improved performance and reduced costs. The Hatfield accident, however, raised awareness of safety. Railtrack, as a private company, was criticised for not investing enough funds into railway maintenance. Against this issue, Railtrack was renationalised into Network Rail, as a result of which safety was secured.

It is undeniable that JNR operated irrespective with market mechanism and its inefficiency caused deficits and decline in service. Privatisation is positively evaluate in that it solved these issues in the mainland. Nevertheless, JR Hokkaido faces difficult situations in safety due to the insufficient investments in railway maintenance. Given the circumstances surrounding JR Hokkaido, governmental support can be validated. This proposes three points; 1) increasing technical support, 2) dividing the company into sales and maintenance department, and 3) making requirements to implement privatization.

\section{Acknowledgement}

I want to thank Mr John Crompton for helping me writing this report.

\section{Reference}

Pollitt, M.G. and Smith, A.S.J. (2002) "The restructuring and privatisation of British Rail: Was it really that bad?" Fiscal Studies, 23 (4). pp. 463-502

Hirooka Haruya (1997) "The Experiences and Lessons of The Privatisation of Japanese National Railways" Hosei University, 34(3), 15-26

Abe Seiji (2014) "The scandals of JR Hokkaido and challenges to regeneration" Saitama University, The Social Science Review (142), pp21-33

Department of Transportation (1992) "New Opportunities for the Railways: The Privatasation of British Rail", Cm. 2012, London: HMSO

Gerald Crompton and Robert Jupe (2003) “Such a Silly Scheme: The Privatisation Of Britain's Railways 19922002" Critical Perspectives on Accounting, Vol 14, Issue 6, pp 617-645

Jean Shaoul (2006) “The Cost of Operating Britain's Privatized Railways" Public Money and Management, 26:3, pp151-158

Francis Terry (2001) "Viewpoints: The Nemesis of Privatization: Railway Policy in Retrospect" Public Money and Management, 21:1, pp 4-6

National Audit Office (2000) "Ensuring that Railtrack Maintain and Renew the Railway Network" 
Daigo Masahide (2006) "Post-Hatfield scheme of British railways and its lesson" The Japan Society of Transportation Economics, Transportation Studies (50), pp 59-68

Robert Jupe (2011) “The Modernisation and Fragmentation of the UK's Transport Infrastructure" Financial Accountability \& Management, Vol. 27, Issue 1, pp. 43-62

Tetria Yunik Dewi Pamungkas, Imam Muthohar (2017) "The Issues of Track Maintenance Management in Indonesia (Based on Study of the British Railways)" Journal of the Civil Engineering Forum, Vol. 3 No. 1 (January 2017), pp 51-60.

Ministry of Land, Infrastructure, Transport and Tourism (MLIT) (2017) "Thirty years after the privatization of JRN"

Matsubara Satoru (1996) “The Reform of JNR and the ten years of JR" Toyo University Economics Report, 22(1), 53-65

Miyashita Hiromi (2017) "On Railway Construction and Transport in Hokkaido: A Review of JR Hokkaido Restructuring of the Railroad Network" The annals of Research Center for Economic and Business Networks (6), pp 145-166

The Hokkaido Press (6 Jan 2020) https://www.hokkaido-np.co.jp/article/380562 